\title{
Lewis acid-driven reaction pathways in synergistic cooperative catalysis over gold/palladium bimetallic nanoparticles for hydrogen autotransfer reaction between amide and alcohol
}

\author{
Hiroyuki Miyamura, Satoshi Isshiki, Hyemin Min, Shū Kobayashi * \\ Department of Chemistry, School of Science, The University of Tokyo, Tokyo 113-0033, Japan
}

\section{A R T I C L E I N F O}

\section{Article history:}

Received 14 April 2016

Accepted 7 June 2016

Published 5 October 2016

\section{Keywords:}

Gold

Palladium

Bimetallic nanoparticle

Lewis acid

Amide synthesis

Hydrogen autotransfer

\begin{abstract}
A B S T R A C T
Metal nanoparticle catalysts, especially gold and its bimetallic nanoparticle catalysts, have been widely used in organic transformations as powerful and green catalysts. The concept of employing two distinct catalysts in one reaction system, such as in cooperative and synergistic catalysis, is a powerful strategy in homogeneous catalysis. However, the adaption of such a strategy to metal nanoparticle catalysis is still under development. Recently, we have found that cooperative catalytic systems of gold/palladium bimetallic nanoparticles and Lewis acid can be used for the $N$-alkylation of primary amides through hydrogen autotransfer reaction between amide and alcohol. Herein, the results of a detailed investigation into the effects of Lewis acids on this hydrogen autotransfer reaction are reported. It was found that the choice of Lewis acid affected not only the reaction pathway leading to the desired product, but also other reaction pathways that produced several intermediates and by-products. Weak Lewis acids, such as alkaline-earth metal triflates, were found to be optimal for the desired N-alkylation of amides.
\end{abstract}

(C) 2016, Dalian Institute of Chemical Physics, Chinese Academy of Sciences. Published by Elsevier B.V. All rights reserved.
Metal nanoparticles have recently attracted much attention as catalysts for organic synthesis because of their unique activities and selectivities, which are derived from both the characteristic nature of their surfaces and their electronic structures [1-11]. Among them, gold and its bimetallic nanoparticles have been found to be excellent catalysts for a range of redox processes such as aerobic oxidation, hydrogenation, and hydrogen transfer reactions [1-4,7,12-19].

We have developed a general strategy to encapsulate various kinds of single and bimetallic nanoparticles in polystyrene-based polymers with cross-linking moieties by using a strategy termed polymer incarceration (PI) [17,18,20]. Using this methodology, we have prepared both single metal and bimetallic nanoparticle catalysts [20-26] and applied these unique catalytic systems to various organic transformations including redox reactions $[20,23,24,26-32]$, cooperative catalysis $[27,33,34]$, multistep tandem processes [30,35,36], and asymmetric transformations (Fig. 1) [37-39]. In these heterogeneous catalysts, metal nanoparticles are stabilized by multiple and weak interactions between the $\pi$-electrons of benzene rings and the surface of the metal nanoparticles. This characteristic interaction results in high activity and increased robustness of the catalysts, and suppresses leaching of metal nanoparticles and their aggregation.

\footnotetext{
*Corresponding author. Tel/Fax: +81-3-5841-4790; E-mail: shu_kobayashi@chem.s.u-tokyo.ac.jp

This work was partially supported by a Grant-in-Aid for Science Research from the Japan Society for the Promotion of Science (JSPS), the Global COE Program, the University of Tokyo, the Japan Science and Technology Agency (JST), and the Ministry of Education, Culture, Sports, Science and Technology (MEXT, Japan).

DOI: 10.1016/S1872-2067(16)62483-X | http://www.sciencedirect.com/science/journal/18722067 | Chin. J. Catal., Vol. 37, No. 10, October 2016
} 

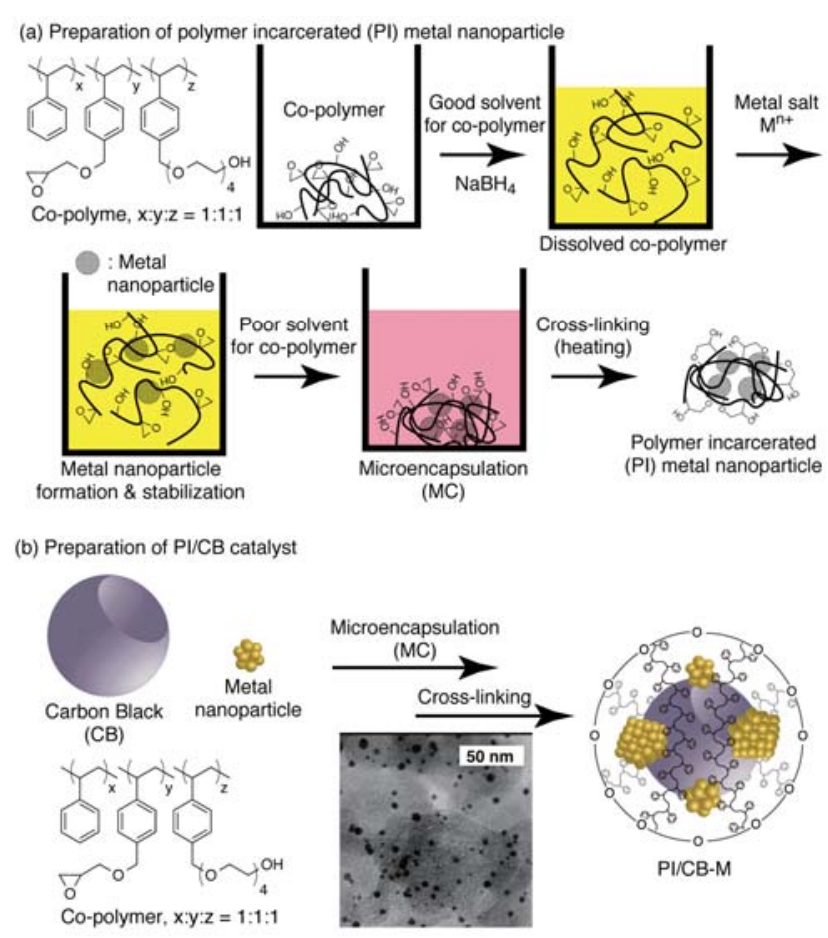

Fig. 1. Schematic image of the PI technique.

Hydrogen transfer/borrowing strategies are useful for conducting both $\mathrm{C}-\mathrm{C}$ and $\mathrm{C}$-heteroatom bond-formation reactions with high atom efficiency because these transformations are redox-neutral overall and no externally added oxidant or reductant is required [40-45]. In addition to the various homogeneous catalysts that have been developed for hydrogen transfer/borrowing reactions, metal nanoparticles have also been demonstrated to be effective catalysts for these transformations [46,47]. The alkylation of amines by using alcohols through hydrogen transfer/borrowing has been widely developed; however, examples of the $N$-alkylation of primary amides are quite limited [48-53]. This could be because amides are generally much less reactive than amines, so nucleophilic attack of a primary amide on an aldehyde generated in situ during the hydrogen transfer/borrowing process is difficult.

The strategy of utilizing two or more catalysts in one reaction system, so called synergistic or cooperative catalysis, is a very powerful tool for catalysis because it can lead to a dramatic reduction in the transition-state energy compared with those for single catalysts [54-56]. There are a number of synergistic or cooperative catalysts that involve metal complexes or organocatalysts; however, systems that are comprised of heterogeneous metal nanoparticles are still developing fields $[27,33,34]$.

Recently, we developed synergistic cascade catalysts composed of a metal Lewis acid and gold/palladium ( $\mathrm{Au} / \mathrm{Pd})$ bimetallic nanoparticles (Scheme 1; Fig. 2) for the $N$-alkylation of a primary amide with a primary alcohol through a hydrogen autotransfer mechanism. In this catalytic system, the choice of Lewis acids is crucial for smooth catalytic turnover and selection of reaction pathways [57]. After extensive optimization of reaction conditions, we have found that using 3 equivalents of

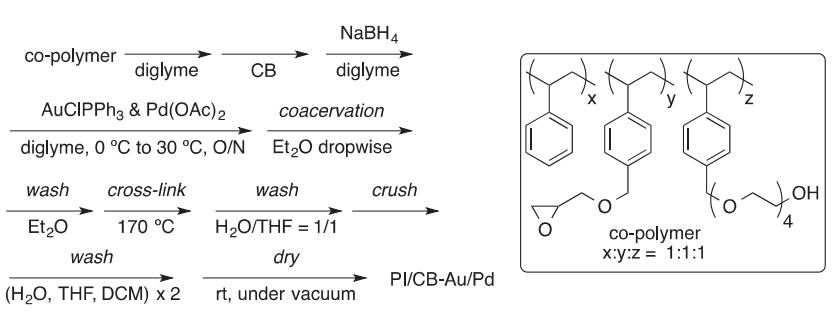

Scheme 1. Preparation of the PI/CB-Au/Pd catalyst.
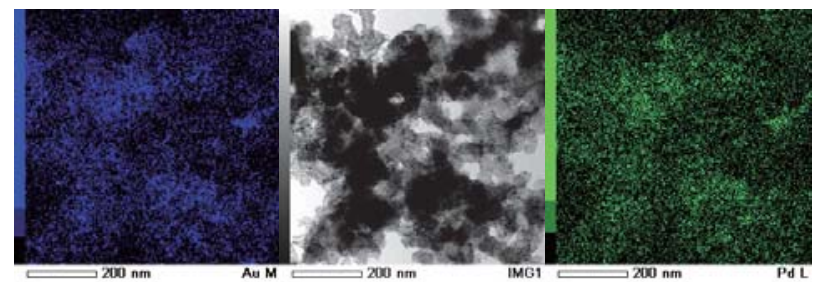

Fig. 2. STEM and EDS images of the PI/CB-Au/Pd catalyst.

alcohol in the presence of $1 \mathrm{~mol} \%$ of PI/CB-Au/Pd and $5 \mathrm{~mol} \%$ of $\mathrm{Ba}(\mathrm{OTf})_{2}$ gave moderate to excellent yields of desired products with wide substrate scope (Scheme 2(a)). In addition, $\mathrm{PI} / \mathrm{CB}-\mathrm{Au} / \mathrm{Pd}$ catalyst can be recovered and reused keeping high activity with simple operation (Scheme 2(b)). Several control experiments suggested that Lewis acids facilitate nucleophilic attack of a primary amide, which has much lower nucleophilicity than the corresponding amine, and this is the key to the success of this relatively challenging hydrogen autotransfer reaction. In the proposed reaction pathways, multiple reaction steps are elaborated and, in addition to the desired product, various intermediates and side-products are also formed (Fig. 3). In this communication, we describe the effect of Lewis acid on the complex reaction schemes in detail and discuss the correlation between the nature of the Lewis acid and the reaction pathway followed.

In a typical experiment, a Carousel $@$ tube was charged with benzamide (30.3 mg, $0.25 \mathrm{mmol}$ ), PI/CB-Au/Pd (11.1 mg, $0.0025 \mathrm{mmol}$ of $\mathrm{Au}$ ) and a stirring bar. The carousel tube was then placed in an argon-filled glovebox. In the glovebox, additives, if any, were added (e.g. Ca(OTf) 2 (4.2 mg, $0.0125 \mathrm{mmol})$ )

$$
\text { (a) }
$$

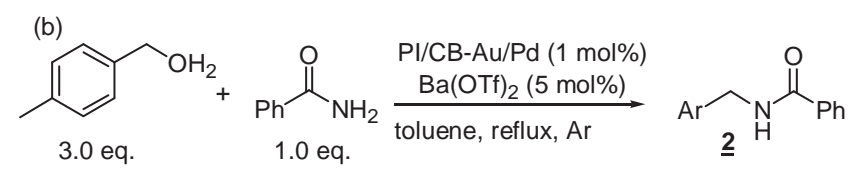

\begin{tabular}{lcccc}
\hline Run & 1 & 2 & 3 & $4-11^{\text {a }}$ \\
\hline Yield (\%) & $>99$ & 99 & 53 & $95-99$
\end{tabular}

a Recovered catalyst was heated at $170{ }^{\circ} \mathrm{C}$ for $5 \mathrm{~h}$ under air before run 4 , 7 , and 10.

Scheme 2. Optimized reaction conditions for substrate scope and recovery \& reuse of catalyst for $N$-alkylation of primary amide [57]. 


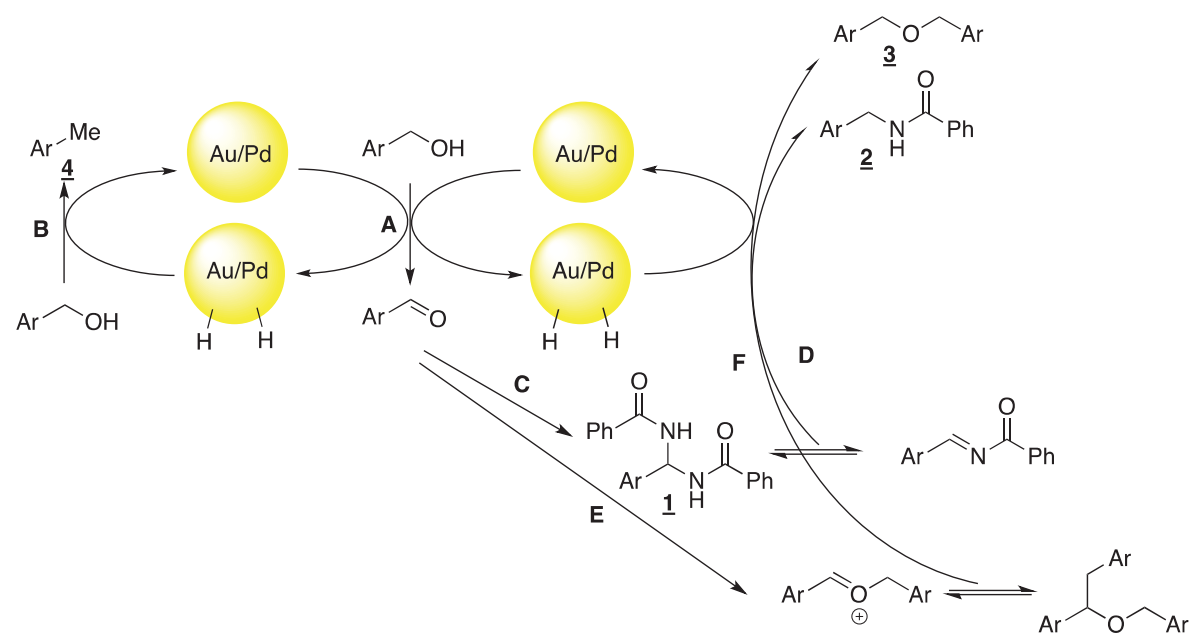

Fig. 3. Expected reaction pathways followed during synergistic cooperative catalysis using Au/Pd bimetallic nanoparticles and Lewis acids.

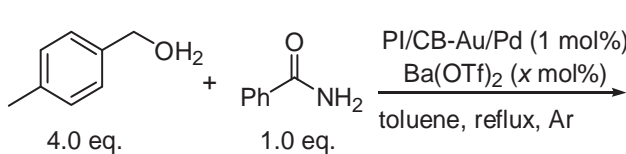<smiles>O=C(NC([Al])NC(=O)c1ccccc1)c1ccccc1</smiles><smiles>CCNC(=O)NCOCN=[W]</smiles>

Scheme 3. General scheme for kinetic investigations using various amount of Ba(OTf $)_{2}$.

and the tube was sealed tightly with a septum. The septum was also taped tightly to the tube and the tube was then removed from the glovebox. 4-Methylbenzyl alcohol (81.1 mg, 0.75 $\mathrm{mmol})$ and toluene $(0.5 \mathrm{~mL})$ were added, and then the part of the septum where the syringe needle went through was covered with tape. The tube was then placed on a Carousel ${ }^{\circledR}$ (parallel synthesiser from Radleys) that had been preheated to 150 ${ }^{\circ} \mathrm{C}$ and it was left to stir for $18 \mathrm{~h}$, after which it was allowed to cool to room temperature. Ethyl acetate was added to dilute the mixture and the GC internal standard (dodecane) was added. An aliquot was passed through Celite into a GC phial and the clear solution was subjected to GC analysis.

Firstly, we examined reaction profiles of $\mathrm{N}$-alkylation of amide through hydrogen autotransfer (Scheme 3) using 1 mol\% of PI/CB-Au/Pd and (0-5) mol\% of Ba(OTf) 2 in order to confirm the synergy between Lewis acid and PI/CB-Au/Pd catalysts. In the presence of $5 \mathrm{~mol} \%$ of $\mathrm{Ba}(\mathrm{OTf})_{2}$, we observed clear induction period for the formation of desired product ( $\underline{2})$ and ether ( $\underline{3}$ ) (Fig. 4). On the other hand, $p$-tolualdehyde and

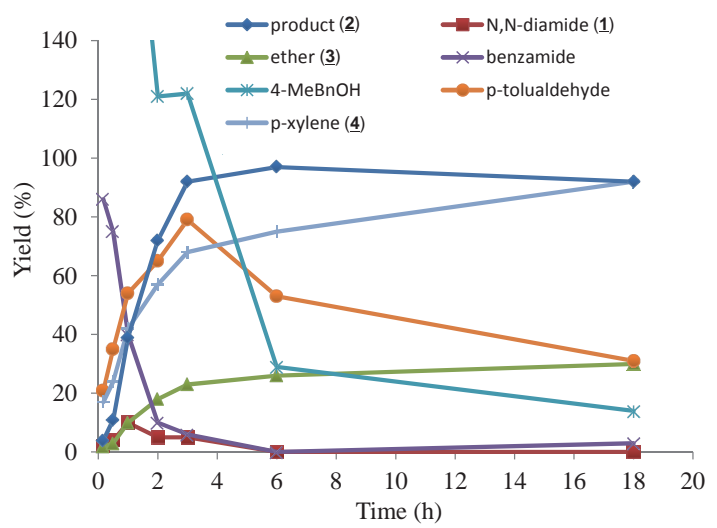

Fig. 4. Reaction profile using $5 \mathrm{~mol} \%$ of $\mathrm{Ba}(\mathrm{OTf})_{2}$. xylene (ㄴ) generated immediately after starting reaction. We also found induction period for generation of $N, N$-diamide ( $\underline{\mathbf{1}})$ and it was steady state intermediate during $0.5-3 \mathrm{~h}$. Yield of desired product reached over $90 \%$ at $6 \mathrm{~h}$ and further prolonging reaction to $18 \mathrm{~h}$ resulted in more consumption of $p$-tolualdehyde and alcohol and increase in amount of xylene (4). When amount of $\mathrm{Ba}(\mathrm{OTf})_{2}$ was reduced to $2.5 \mathrm{~mol} \%$ (Fig. $5)$, generation speed of desired product $(\underline{\mathbf{2}})$ and ether $(\underline{\mathbf{3}})$ decreased dramatically especially at initial stage $(0.5-3 \mathrm{~h})$, while initial production ratio of $p$-tolualdehyde and xylene ( $\underline{4})$ was almost same as the case using $5 \mathrm{~mol} \%$ of $\mathrm{Ba}(\mathrm{OTf})_{2}$. When amount of $\mathrm{Ba}(\mathrm{OTf})_{2}$ was further reduced to $1 \mathrm{~mol} \%$ (Fig. 6), longer induction periods $(\sim 2 \mathrm{~h})$ for product $(\underline{\mathbf{2}})$ and ether $(\underline{\mathbf{3}})$ were observed and concentration of $N, N$-diamide ( $\underline{\mathbf{1}}$ ) at steady state decreased, while initial production ratio of $p$-tolualdehyde was almost same as the case using $5 \mathrm{~mol} \%$ of $\mathrm{Ba}(\mathrm{OTf})_{2}$. When $\mathrm{Ba}(\mathrm{OTf})_{2}$ was not used, very low production ratio for desired product ( $\underline{2})$ was observed and only $30 \%$ yield was obtained at $18 \mathrm{~h}$ (Fig. 7). On the other hand, still similar production ratio of

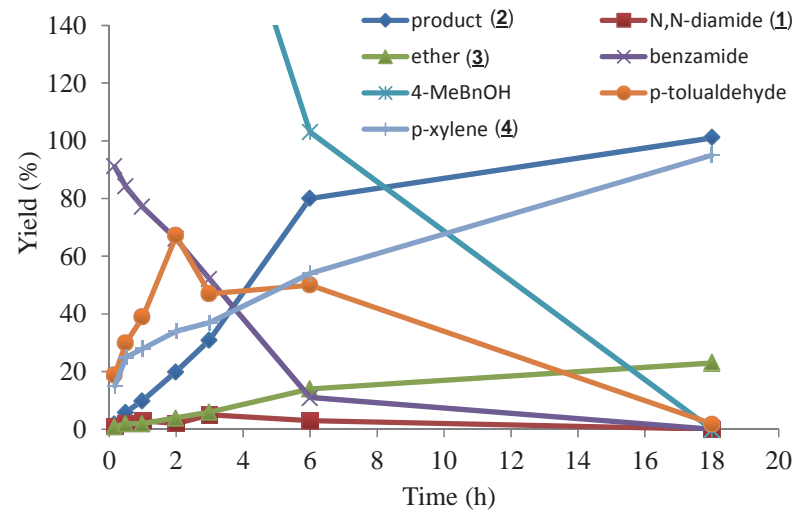

Fig. 5. Reaction profile using $2.5 \mathrm{~mol} \%$ of $\mathrm{Ba}(\mathrm{OTf})_{2}$. 


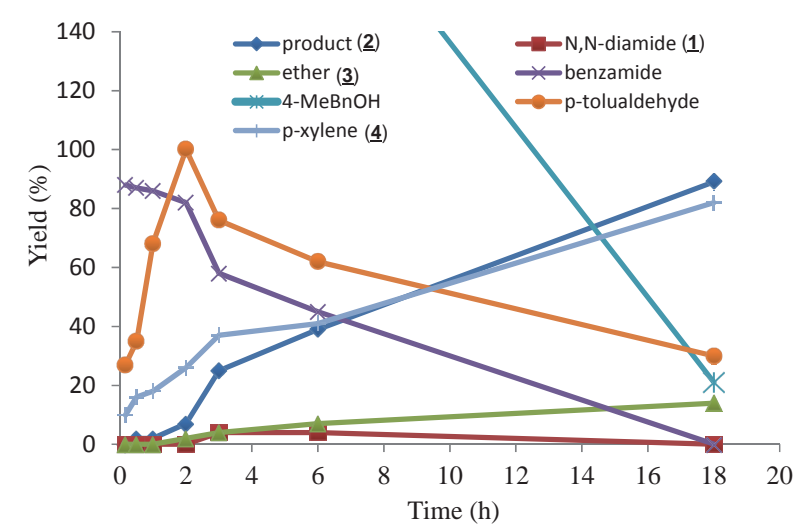

Fig. 6. Reaction profile using $1 \mathrm{~mol} \%$ of $\mathrm{Ba}(\mathrm{OTf})_{2}$.

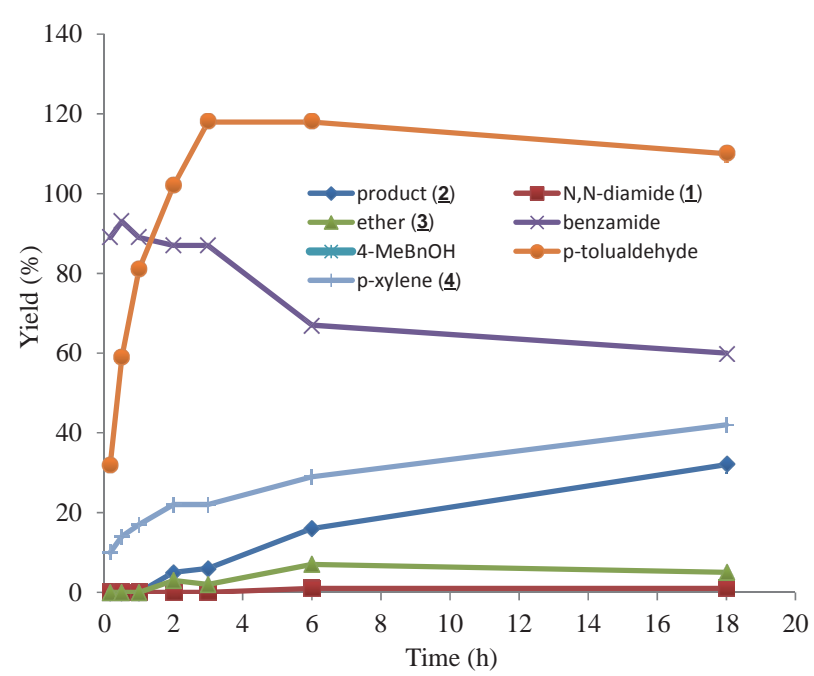

Fig. 7. Reaction profile without $\mathrm{Ba}(\mathrm{OTf})_{2}$.

$p$-tolualdehyde was observed at initial stage. Almost similar production ratio of $p$-tolualdehyde at initial stage regardless of amount of $\mathrm{Ba}(\mathrm{OTf})_{2}$ clearly indicated that no participation of $\mathrm{Ba}(\mathrm{OTf})_{2}$ in the step A (Fig. 3). On the other hand, concentration of $p$-tolualdehyde at middle stage, at which $N, N$-diamide ( $\underline{\mathbf{1}})$ was observed as steady state intermediate and concentration of desired product ( $\underline{\mathbf{2}})$ increased constantly, as the amount of $\mathrm{Ba}(\mathrm{OTf})_{2}$ increased. These paradoxical results were resulted from the acceleration of catalytic turnover of $\mathrm{PI} / \mathrm{CB}-\mathrm{Au} / \mathrm{Pd}$ through synergistic cooperation of Lewis acids, that will be discussed later.

Condensation between $p$-tolualdehyde and benzamide was investigated in the presence of various Lewis acids without $\mathrm{PI} / \mathrm{CB}-\mathrm{Au} / \mathrm{Pd}$ (Table 1). Reactions were conducted using 1 mol\% of Lewis acids for $1 \mathrm{~h}$. Surprisingly, the optimized Lewis acid, $\mathrm{Ba}(\mathrm{OTf})_{2}$, in previous study did not accelerate condensation so much as well as other alkaline earth metal triflates (entries 1-3 vs. 8). As we expected, stronger Lewis acids, such as $\mathrm{Sc}$ and $\mathrm{Yb}$ triflates, showed dramatic acceleration of the condensation (entries 4-7). It was clear that Lewis acids play very important role in step $\mathrm{C}$ even in the absence of PI/CB-Au/Pd (Fig. 3).

Next, we moved on the investigation of effect of various Lewis acids on the reactivity and selectivity in $\mathrm{N}$-alkylation of
Table 1

Condensation between tolualdehyde and benzamide.

\begin{tabular}{llc}
0.75 eq. & Lewis acid & Yield $\underline{\mathbf{1}}(\%)$ \\
\hline Entry & $\mathrm{Ba}(\mathrm{OTf})_{2}$ & 10 \\
2 & $\mathrm{Ca}(\mathrm{OTf})_{2}$ & 15 \\
3 & $\mathrm{Mg}(\mathrm{OTf})_{2}$ & 34 \\
4 & $\mathrm{Sc}(\mathrm{OTf})_{3}$ & $>99$ \\
5 & $\mathrm{Yb}(\mathrm{OTf})_{3}$ & $>99$ \\
7 & $\mathrm{Cu}(\mathrm{OTf})_{2}$ & $>99$ \\
8 & $\mathrm{Al}(\mathrm{OTf})_{3}$ & 59 \\
\hline
\end{tabular}

amide through hydrogen autotransfer. Although we have been able to obtain quantitative yield of desired products ( $\underline{\mathbf{2}})$ using 3 equivalents of benzylic alcohol, in this study we analyzed the products and intermediates formed by using 1.5 equivalents of 4-methyl benzyl alcohol as a starting material in order to emphasize the difference in results and evaluated the reaction pathways that were accelerated by Lewis acids. We examined the use of a selection of metal Lewis acids ( $\mathrm{Li}, \mathrm{Ca}, \mathrm{Ba}, \mathrm{Mg}, \mathrm{Zn}, \mathrm{Cu}$, $\mathrm{Fe}, \mathrm{Sn}, \mathrm{Ce}, \mathrm{Sm}, \mathrm{Sc}, \mathrm{Bi}, \mathrm{In}, \mathrm{Hf}$, and $\mathrm{Yb}$ ) as cations, and halides, sulfate, triflate, hydroxide, and alkoxide as anions (Table 2).

It was assumed that the Lewis acid did not influence step A significantly as we discussed in previous chapter. The other steps are highly dependent on the type of Lewis acid employed, with the most important feature of the Lewis acid being the selective activation of either the aldehyde or amide [58]. In Table 2, entries 1-6, the Lewis acids are thought to activate the aldehyde selectively and either $\underline{\mathbf{3}}$ step $\mathbf{E}$ or $\mathbf{F}$, or both steps are accelerated. As a result, the ether was obtained rather than the $\mathrm{N}, \mathrm{N}$-diamide $\underline{\mathbf{1}}$ or the desired amide product $\underline{\mathbf{2}}$. This tendency is supported by reports that $\mathrm{Bi}(\mathrm{OTf})_{3}, \mathrm{BiBr}_{3}, \mathrm{Cu}(\mathrm{OTf})_{2}$, or In(OTf) can be used as catalysts or activators in hydroxymethylation or reductive coupling reactions with aldehydes $[59,60]$. Some alkali-earth and rare-earth metal (lanthanides) cations are known to be effective catalysts for the activation of amides or carbamates [61,62]. In entries 7-19, Lewis acids containing these kinds of metals were used; in this case, although the desired product $\underline{\mathbf{2}}$ was obtained selectively, a large amount of xylene $\underline{4}$ was also formed. We concluded that both the Lewis acidity and the basicity of the counteranion of these Lewis acids were important factors that determined the rate of formation of $N, N$-diamide $\underline{\mathbf{1}}$ or product amide $\underline{\mathbf{2}}$ (steps $\mathbf{C}$ or $\mathbf{D}$, or both steps). At the same time, xylene $\underline{\mathbf{4}}$ formation (step B) was also strongly accelerated by using these Lewis acids. Reactions catalyzed by alkaline-earth metal ( $\mathrm{Ca}, \mathrm{Ba}$, and $\mathrm{Mg}$ ) triflates, showed particularly high selectivity toward formation of the desired product (entries 7, 11, and 13). The Lewis acids shown in entries 20-23 were too weak to form the product amide, although the $\mathrm{N}, \mathrm{N}$-diamide intermediate was generated (step C was accelerated, but not step D). The "borrowed" hydrogen is returned to the alcohols selectively and, as a result, relatively high yields of the $\mathrm{N}, \mathrm{N}$-diamide and xylene were obtained. The alcohols are consumed in the formation of xylene and, ulti- 
Table 2

Effect of Lewis acids on the $N$-alkylation of a primary amide through hydrogen autotransfer.

\begin{tabular}{|c|c|c|c|c|c|}
\hline \multirow{2}{*}{ Entry } & \multirow{2}{*}{ Lewis acid } & \multicolumn{4}{|c|}{ Yield (\%) } \\
\hline & & $\underline{1}$ & $\underline{2}$ & $\underline{3}$ & $\underline{4}$ \\
\hline 1 & $\mathrm{Bi}(\mathrm{OTf})_{3}$ & 0 & 30 & 50 & 6 \\
\hline 2 & $\mathrm{BiBr}_{3}$ & 2 & 12 & 32 & trace \\
\hline 3 & $\operatorname{In}(\mathrm{OTf})_{3}$ & 4 & 22 & 50 & 8 \\
\hline 4 & $\operatorname{Sn}(\mathrm{OTf})_{2}$ & 4 & 33 & 50 & 8 \\
\hline 5 & $\mathrm{Cu}(\mathrm{OTf})_{2}$ & 4 & 31 & 50 & 8 \\
\hline 6 & $\mathrm{Cu}(\mathrm{OTf})$ & 7 & 36 & 32 & 14 \\
\hline 7 & $\mathrm{Ba}(\mathrm{OTf})_{2}$ & 2 & 72 & 2 & 29 \\
\hline 8 & $\mathrm{BaSO}_{4}$ & 0 & 40 & 1 & 33 \\
\hline 9 & $\mathrm{Yb}(\mathrm{OTf})_{3}$ & 10 & 50 & 7 & 42 \\
\hline 10 & $\mathrm{Sc}(\mathrm{OTf})_{3}$ & 12 & 44 & 6 & 43 \\
\hline 11 & $\operatorname{Mg}(\mathrm{OTf})_{2}$ & 4 & 67 & 2 & 30 \\
\hline 12 & Li(OTf) & 0 & 45 & 2 & 30 \\
\hline 13 & $\mathrm{Ca}(\mathrm{OTf})_{2}$ & 2 & 59 & 2 & 28 \\
\hline 14 & $\mathrm{CaSO}_{4}$ & 0 & 37 & 1 & 28 \\
\hline 15 & $\mathrm{Bi}_{2}\left(\mathrm{SO}_{4}\right)_{3}$ & 5 & 40 & 2 & 41 \\
\hline 16 & $\begin{array}{c}4 \mathrm{BiNO}_{3}(\mathrm{OH})_{2} \\
\mathrm{BiO}(\mathrm{OH})\end{array}$ & 4 & 42 & 2 & 22 \\
\hline 17 & $\mathrm{ZnCl}_{2}$ & 21 & 42 & 1 & 47 \\
\hline 18 & $\mathrm{ZnSO}_{4}$ & 6 & 58 & 1 & 41 \\
\hline 19 & $\mathrm{CuSO}_{4}$ & 16 & 47 & 11 & 24 \\
\hline 20 & $\mathrm{BiF}_{3}$ & 18 & 26 & 2 & 25 \\
\hline 21 & $\mathrm{ZnF}_{2}$ & 21 & 2 & 5 & 47 \\
\hline 22 & $\mathrm{In}_{2}\left(\mathrm{SO}_{4}\right)_{3}$ & 40 & 14 & 4 & 60 \\
\hline 23 & $\mathrm{Fe}_{2}\left(\mathrm{SO}_{4}\right)_{3}$ & 39 & 16 & 5 & 58 \\
\hline 24 & $\mathrm{Ce}(\mathrm{OTf})_{4}$ & 20 & 25 & 11 & 43 \\
\hline 25 & $\operatorname{Sm}(\mathrm{OTf})_{3}$ & 19 & 24 & 11 & 42 \\
\hline 26 & $\mathrm{Hf}(\mathrm{OTf})_{4}$ & 19 & 25 & 11 & 43 \\
\hline 27 & $\mathrm{Zn}(\mathrm{OTf})_{2}$ & 5 & 22 & 21 & 33 \\
\hline 28 & $\mathrm{Al}(\mathrm{OTf})_{3}$ & 4 & 16 & 25 & 30 \\
\hline 29 & $\mathrm{Zn}(\mathrm{OtBu})_{2}$ & 14 & 2 & 23 & 93 \\
\hline
\end{tabular}

* Yield was calculated based on the amount of benzamide used (Yield = (mmol of compound)/(mmol of used benzamide)).

mately, no alcohols remain for reduction of the $\mathrm{N}, \mathrm{N}$-diamide intermediate and for aldehyde formation to proceed in the next catalytic cycle. In entries 24-26, relatively high yields of the $\mathrm{N}, \mathrm{N}$-diamide and xylene were also observed, but the yields of the amide product and the ether were also high compared with the results presented in entries 20-23. We suggest that this is probably because of too strong Lewis acidity [63]; they activate both aldehyde and amide moieties in all steps, thereby eliminating the specific selectivity. From the results, however, it seems that the formation of xylene (step B) is easier than the other steps. In entries 27-28, almost no selectivity was observed; however, less acceleration for the formation of $\mathrm{N}, \mathrm{N}$-diamide (step C or D) and greater acceleration for formation of the ether (step $\mathbf{E}$ or B) was observed compared with the results presented in entries 24-26. In the presence of a strong basic cocatalyst, the desired pathway did not proceed and only step B was accelerated (entry 29). Under strongly basic conditions, activation of the amide is difficult and the formation of the $N, N$-diamide (step C) is suppressed. At the same time, dehydrogenation from the alcohol to the aldehyde (step A) can be accelerated and generated hydrogen is consumed for reduction of the alcohol to xylene (step B). A similar tendency to produce very little of the desired product was observed in our previous trial when basic molecular sieves MS3A or $4 \mathrm{~A}$ was used as an additive [57].

Synergistic cooperative effect between $\mathrm{Au} / \mathrm{Pd}$ nanoparticle catalyst and Lewis acid catalyst is shown in their reaction mechanism (Fig. 3). The reaction is initiated by the accumulation of the aldehyde (step A) and it results in the formation of xylene accompanying consumption of sacrificial alcohols (step B). Then, aldehyde reacts with primary amide or alcohol to form hydrogen acceptors such as $\mathrm{N}, \mathrm{N}$-diamide (step C) or oxocarbenium ion (step E), and hydrogen returning to these hydrogen acceptors affords desired amide product (step D) or ether as side product (step F).

Large amount of aldehyde was observed at the early stage of the reaction regardless of the presence of Lewis acids, while the xylene was steadily formed. Aldehyde and xylene were formed even in the reaction without Lewis acid (Fig. 7; in this case, $\mathrm{Ba}(\mathrm{OTf})_{2}$ ) through disproportionation-like reaction (Step A and B). Yield of the desired product was very low and $\mathrm{N}, \mathrm{N}$-diamide intermediate was not detected in the absence of Lewis acid (Fig. 7). However, when Lewis acid was used, the rate of the formation of the desired product, xylene and ether was increased and this rate was correlated with the amount of $\mathrm{Ba}(\mathrm{OTf})_{2}$ because of Lewis acid acceleration (Figs. 4-6). In addition, we could see $\mathrm{N}, \mathrm{N}$-diamide intermediate in a certain concentration at steady state.

This Lewis acid acceleration also made alcohol consumption much faster (steps $\mathbf{A}$ and $\mathbf{B}$ ). In terms of the yield and rate of desired product formation, swift increase in the yield of desired product was observed after several times (induction period), and this period was almost corresponded to that of steady amount of $\mathrm{N}, \mathrm{N}$-diamide. During this period, the amount of aldehyde was significantly increased and reached to steady state; it implies that accumulation of aldehyde is needed for initiation of the desired product formation.

In this reaction mechanism, $\mathrm{Au} / \mathrm{Pd}$ nanoparticle catalyst played important role in hydrogen transfer from alcohol (step A) to the various hydrogen acceptors (steps $\mathbf{F}$ and $\mathbf{D}$ ), on the other hand, Lewis acid mainly worked in $\mathrm{N}, \mathrm{N}$-diamide formation, carbonium cation formation (steps $\mathbf{C}$ and $\mathbf{E}$ ) and hydrogen returning (steps $\mathbf{F}$ and $\mathbf{D}$ ). Those steps are intimately connected; in hydrogen returning step (steps $\mathbf{F}$ and $\mathbf{D}$ ) (even there is competition between desired reaction pathway and side reaction pathway), the rate of these steps would be affected by the amount or the formation rate of hydrogen acceptors, which is catalyzed by Lewis acids. Faster hydrogen returning would accelerate the $\mathrm{Au} / \mathrm{Pd}$ catalyst turnover and it results in production of more aldehyde, then successive formation of hydrogen acceptors would occur. Formation of xylene (step B) is also highly affected by the presence of Lewis acids indirectly. High $\mathrm{Au} / \mathrm{Pd}$ nanoparticle catalyst turnover, which depends on the generation speed of hydrogen accepters catalyzed by Lewis acids, would also accelerate step B. As a result, acceleration of 
various steps by Lewis acids would bring faster catalytic turnover of $\mathrm{Au} / \mathrm{Pd}$ nanoparticle catalyst, in other words, cooperative catalytic effect of $\mathrm{Au} / \mathrm{Pd}$ nanoparticle catalyst and Lewis acids is exist and the yields of desired product and side product are highly depended on choice of Lewis acids. As we discussed in previous section, concentration of aldehyde at steady state is inversely proportional to the amount of Lewis acid (Figs. 4-6), because lower concentration of aldehyde is sufficient for the generation speed of hydrogen acceptors to form, that can make up for their consumption speed in hydrogen returning at the steady state, in the presence of larger amount of Lewis acid.

In summary, we have investigated the effect of Lewis acids that show a synergistic cooperative effect with $\mathrm{Au} / \mathrm{Pd}$ nanoparticle catalysts on the $\mathrm{N}$-alkylation of a primary amide through hydrogen autotransfer. On the one hand, the reaction pathways are strongly influenced by the character of the Lewis acids. For example, Lewis acids such as $\mathrm{Bi}(\mathrm{OTf})_{3}, \mathrm{BiBr}_{3}, \mathrm{Cu}(\mathrm{OTf})_{2}$, or $\operatorname{In}(\mathrm{OTf})_{3}$, gave dibenzyl ether selectively even in the presence of a primary amide because of their strong activation of the aldehyde. On the other hand, alkaline-earth metal triflates provided the desired amide selectively, probably because of effective coordination by the amide moiety of the $\mathrm{N}, \mathrm{N}$-diamide intermediate to the metal center during reduction by hydrogenated $\mathrm{Au} / \mathrm{Pd}$ bimetallic nanoparticles. We also found that some Lewis acids accelerated the reductive dehydroxylation of benzylic alcohol selectively. The interesting findings concerning Lewis acid-driven reaction pathways reported in this study provide new possibilities and directions for the further design of cooperative catalytic systems involving metal nanoparticles.

\section{Acknowledgments}

We also thank Mr. Noriaki Kuramitsu (The University of Tokyo) for STEM and EDS analysis.

\section{References}

[1] N. Toshima, T. Yonezawa, New J. Chem., 1998, 22, 1179-1201.

[2] M. Haruta, Chem. Rec., 2003, 3, 75-87.

[3] M. Haruta, Nature, 2005, 437, 1098-1099.

[4] M. Haruta, ChemPhysChem, 2007, 8, 1911-1913.

[5] T. Ishida, M. Haruta, Angew. Chem. Int. Ed., 2007, 46, 7154-7156.

[6] T. Mallat, E. Orglmeister, A. Baiker, Chem. Rev., 2007, 107, 4863-4890.

[7] T. Tsukuda, H. Tsunoyama, H. Sakurai, Chem. Asian J., 2011, 6, 736-748.

[8] H. Cong, J. A. Jr. Porco, ACS Catal., 2012, 2, 65-70.

[9] N. Dimitratos, J. A. Lopez-Sanchez, G. J. Hutchings, Chem. Sci., 2012, $3,20-44$

[10] A. Taketoshi, M. Haruta, Chem. Lett., 2014, 43, 380-387.

[11] T. Yasukawa, H. Miyamura, S. Kobayashi, Chem. Soc. Rev., 2014, 43, 1450-1461.

[12] M. Haruta, T. Kobayashi, H. Sano, N. Yamada, Chem. Lett., 1987, 405-408.

[13] M. Haruta, N. Yamada, T. Kobayashi, S. Iijima, J. Catal., 1989, 115, 301-309.

[14] A. Corma, H. García, Chem. Soc. Rev., 2008, 37, 2096-2126.

[15] A. Corma, A. Leyva-Pérez, M. J. Sabater, Chem. Rev., 2011, 111, 1657-1712.

[16] Y. Zhang, X. J. Cui, F. Shi, Y. Q. Deng, Chem. Rev., 2012, 112, 2467-2505.

[17] H. Miyamura, S. Kobayashi, Acc. Chem. Res., 2014, 47, 1054-1066.

[18] S. Kobayashi, H. Miyamura, Aldrichim. Acta, 2013, 46, 3-19.

[19] S. Kobayashi, H. Miyamura, Chem. Rec., 2010, 10, 271-290.

[20] H. Miyamura, R. Matsubara, Y. Miyazaki, S. Kobayashi, Angew. Chem. Int. Ed., 2007, 46, 4151-4154.

[21] C. Lucchesi, T. Inasaki, H. Miyamura, R. Matsubara, S. Kobayashi, Adv. Synth. Catal., 2008, 350, 1996-2000.

[22] H. Miyamura, R. Matsubara, S. Kobayashi, Chem. Commun., 2008, 2031-2033.

[23] K. Kaizuka, H. Miyamura, S. Kobayashi, J. Am. Chem. Soc., 2010,

\section{Graphical Abstract}

Chin. J. Catal., 2016, 37: 1662-1668 doi: 10.1016/S1872-2067(16)62483-X

Lewis acid-driven reaction pathways in synergistic cooperative catalysis over gold/palladium bimetallic nanoparticles for hydrogen autotransfer reaction between amide and alcohol

Hiroyuki Miyamura, Satoshi Isshiki, Hyemin Min, Shū Kobayashi * The University of Tokyo, Japan

The choice of Lewis acid determines the course of $N$-alkylation of a primary amide through hydrogen autotransfer reaction catalyzed by cooperative catalytic systems composed of $\mathrm{Au} / \mathrm{Pd}$ bimetallic nanoparticles and Lewis acid, and directs the course of the reaction towards the desired product or by-product.

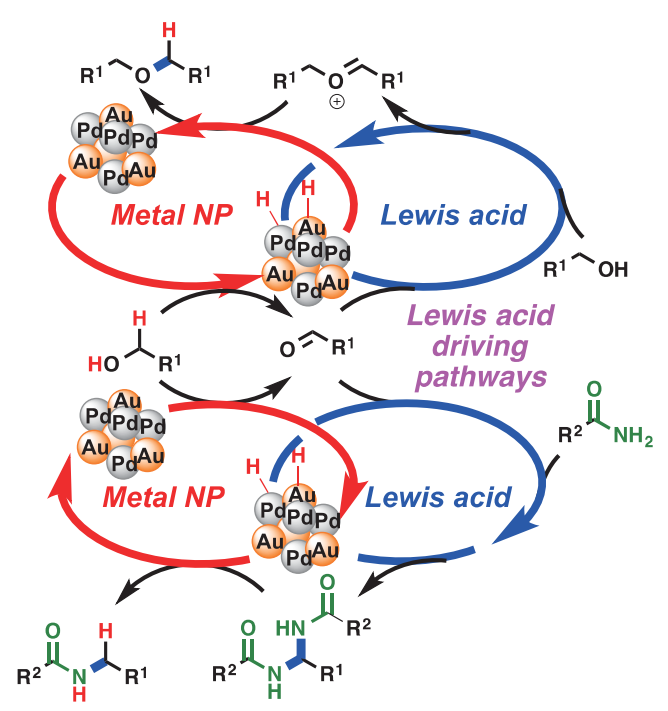


132, 15096-15098

[24] H. Miyamura, M. Morita, T. Inasaki, S. Kobayashi, Bull. Chem. Soc. Jpn., 2011, 84, 588-599.

[25] J. F. Soule, H. Miyamura, S. Kobayashi, Chem. Asian J., 2013, 8, 2614-2626.

[26] H. Miyamura, T. Yasukawa, S. Kobayashi, Tetrahedron, 2014, 70, 6039-6049.

[27] H. Yuan, W. J. Yoo, H. Miyamura, S. Kobayashi, J. Am. Chem. Soc., 2012, 134, 13970-13973.

[28] J.-F. Soule, H. Miyamura, S. Kobayashi, Asian J. Org. Chem., 2012, 1, 319-321.

[29] H. Miyamura, S. Kobayashi, Chem. Lett., 2012, 41, 976-978.

[30] J. F. Soule, H. Miyamura, S. Kobayashi, J. Am. Chem. Soc., 2011, 133, 18550-18553.

[31] H. Miyamura, T. Yasukawa, S. Kobayashi, Green Chem., 2010, 12, 776-778.

[32] H. Miyamura, M. Shiramizu, R. Matsubara, S. Kobayashi, Angew. Chem. Int. Ed., 2008, 47, 8093-8095.

[33] H. Miyamura, K. Maehata, S. Kobayashi, Chem. Commun., 2010, 46, 8052-8054.

[34] H. Yuan, W.-J. Yoo, H. Miyamura, S. Kobayashi, Adv. Synth. Catal,, 2012, 354, 2899-2904.

[35] H. Miyamura, A. Suzuki, T. Yasukawa, S. Kobayashi, Adv. Synth. Catal., 2015, 357, 3815-3819.

[36] W. J. Yoo, H. Miyamura, S. Kobayashi, J. Am. Chem. Soc., 2011, 133, 3095-3103.

[37] T. Yasukawa, A. Suzuki, H. Miyamura, K. Nishino, S. Kobayashi, J. Am. Chem. Soc., 2015, 137, 6616-6623.

[38] H. Miyamura, G. C. Y. Choo, T. Yasukawa, W. J. Yoo, S. Kobayashi, Chem. Commun., 2013, 49, 9917-9919.

[39] T. Yasukawa, H. Miyamura, S. Kobayashi, J. Am. Chem. Soc., 2012, 134, 16963-16966.

[40] F. Alonso, P. Riente, M. Yus, Acc. Chem. Res., 2011, 44, 379-391.

[41] G. E. Dobereiner, R. H. Crabtree, Chem. Rev., 2010, 110, 681-703.

[42] G. Guillena, D. J. Ramón, M. Yus, Chem. Rev., 2010, 110, 1611-1641.
[43] M. H. S. A. Hamid, P. A. Slatford, J. M. J. Williams, Adv. Synth. Catal., 2007, 349, 1555-1575.

[44] T. D. Nixon, M. K. Whittlesey, J. M. J. Williams, Dalton Trans., 2009, 753-762.

[45] A. J. A. Watson, J. M. J. Williams, Science, 2010, 329, 635-639.

[46] X. Liu, R. S. Ding, L. He, Y. M. Liu, Y. Cao, H. Y. He, K. N. Fan, ChemSusChem, 2013, 6, 604-608.

[47] K. I. Shimizu, N. Imaiida, K. Kon, S. M. A. H. Siddiki, A. Satsuma, ACS Catal., 2013, 3, 998-1005.

[48] Y. Watanabe, T. Ohta, Y. Tsuji, Bull. Chem. Soc. Jpn., 1983, 56, 2647-2651.

[49] K. I. Fujita, A. Komatsubara, R. Yamaguchi, Tetrahedron, 2009, 65, 3624-3628.

[50] X. J. Cui, Y. Zhang, F. Shi, Y. Q. Deng, Chem. Eur. J., 2011, 17, 1021-1028.

[51] A. J. A. Watson, A. C. Maxwell, J. M. J. Williams, J. Org. Chem., 2011, 76, 2328-2331.

[52] F. Li, P. P. Qu, J. Ma, X. Y. Zou, C. L. Sun, ChemCatChem, 2013, 5, 2178-2182.

[53] A. Martínez-Asencio, M. Yus, D. J. Ramón, Synthesis, 2011, 3730-3740.

[54] A. E. Allen, D. W. C. MacMillan, Chem. Sci., 2012, 3, 633-658.

[55] N. T. Patil, V. S. Shinde, B. Gajula, Org. Biomol. Chem., 2012, 10, 211-224.

[56] Z. T. Du, Z. H. Shao, Chem. Soc. Rev., 2013, 42, 1337-1378.

[57] G. C. Y. Choo, H. Miyamura, S. Kobayashi, Chem. Sci., 2015, 6, 1719-1727.

[58] S. Kobayashi, T. Busujima, S. Nagayama, Chem. Eur. J., 2000, 6, 3491-3494.

[59] S. Kobayashi, T. Ogino, H. Shimizu, S. Ishikawa, T. Hamada, K. Manabe, Org. Lett., 2005, 7, 4729-4731.

[60] T. Mineno, R. Tsukagoshi, T. Iijima, K. Watanabe, H. Miyashita, H. Yoshimitsu, Tetrahedron Lett., 2014, 55, 3765-3767.

[61] S. Saito, S. Kobayashi, J. Am. Chem. Soc., 2006, 128, 8704-8705.

[62] H. Van Nguyen, R. Matsubara, S. Kobayashi, Angew. Chem. Int. Ed., 2009, 48, 5927-5929.

[63] M. Noji, Y. Konno, K. Ishii, J. Org. Chem., 2007, 72, 5161-5167.

\title{
金/钯双金属纳米颗粒协同催化酰胺和醇间氢自转移反应中 路易斯酸驱动反应路径
}

\author{
Hiroyuki Miyamura, Satoshi Isshiki, Hyemin Min, Shū Kobayashi ${ }^{*}$ \\ 东京大学理学院化学系, 东京113-0033, 日本
}

摘要: 金属纳米颗粒, 特别是金和它的双金属纳米颗粒作为强大的绿色催化剂广泛用于有机合成反应中. 在一个反应体系 中使用 2 个不同催化剂(如协同催化), 在均相催化中是一个很好的策略. 然而, 这种方法仍在发展中. 最近我们发现, 金/钯 双金属纳米颗粒与路易斯酸的协同催化体系可用于伯胺的 $\mathrm{N}-$ 烷基化: 即酰胺与醇之间的氢自转移反应. 我们详细报道了 路易斯酸对该氢自转移反应的影响. 结果表明, 所选的路易斯酸不仅影响生成目标产物的反应路径, 而且影响生成多个中 间体和副产物的反应路径. 弱的路易斯酸, 如三氟甲磺酸碱土金属盐, 非常适合酰胺的 $\mathrm{N}-$-烷基化反应.

关键词: 金; 钯; 双金属纳米颗粒; 路易斯酸; 酰胺合成; 氢自转移

收稿日期: 2016-04-14. 接受日期: 2016-06-07. 出版日期: 2016-10-05.

*通讯联系人. 电话/传真: +81-3-5841-4790; 电子信箱: shu_kobayashi@chem.s.u-tokyo.ac.jp

本文的英文电子版由Elsevier出版社在ScienceDirect上出版(http://www.sciencedirect.com/science/journal/18722067). 